TOLL-ПОДОБНЫЕ РЕЦЕПТОРЫ КАК ПАРАДИГМА КЛЕТКИ

\author{
Александр Николаевич Полторак \\ Университет Тафтса, Департамент Патологии, Бостон, США \\ 150 Harrison Avenue, Boston, MA 02111 \\ alexander.poltorak@tufts.edu
}

Петрозаводский государственный университет, Петрозаводск, Россия

185910, Петрозаводск, пр-т Ленина, 33

Лаборатория молекулярной генетики врожденного иммунитета

\begin{abstract}
Аннотация. Toll-подобные рецепторы (TLR), опосредующие распознавание молекулярных структур патогенов, экспрессируются на клетках разных типов, инициируя развитие иммунных реакций при связывании с различными лигандами. Несмотря на то, что у ряда организмов идентифицированы функциональные TLR, их биологическая роль и механизмы функционирования до конца не изучены.
\end{abstract}

Ключевые слова: Toll-подобные рецепторы, сигнальные каскады, паттерны, адаптерные белки, цитокины, макрофаги. 


\title{
TOLL-LIKE RECEPTOR AS A PARADIGM OF THE CELL
}

\section{Alexander N. Poltorak}

Tufts University School of Medicine, Department of Pathology, Boston, USA

150 Harrison Avenue, Boston, MA 02111

alexander.poltorak@tufts.edu

Petrozavodsk State University, Petrozavodsk, Russia

33 Lenin Avenue, Petrozavodsk, 185910

Laboratory of Molecular Genetics of Innate Immunity

\begin{abstract}
Toll-like receptors (TLR) mediate recognition of molecular structures of pathogens. TLRs are expressed on cells of different types and initiate immune response by binding to different ligands. Despite the fact that functional TLRs were identified in several organisms including human and mouse their biological role and mechanisms of functioning are insufficiently studied.
\end{abstract}

Keywords: Toll-like receptors, signaling cascades, patterns, adaptor proteins, cytokines, macrophages. 
Распознавание патогенов микробного происхождения является основополагающим компонентом иммунного ответа, включающим воспаление (Janeway, 1998). Этот ответ опосредуется рецепторами особого семейства, узнающими наиболее общие молекулярные компоненты (паттерны, PAMP - Pathogen Associated Molecular Patterns) микробов (вирусов, бактерий, паразитов и т.д.) и получившими название PRR (Pattern Recognition Receptors) (Medzhitov, 2000). После узнавания соответствующего специфического паттерна PRR запускают серию сигнальных каскадов, которые представляют собой первую линию защиты от микробов. Кроме того, инициируемый PRR сигнал запускает созревание дендритных клеток, которые подготавливают вторую линию иммунного ответа на инфекцию, известную как приобретенный иммунитет.

Toll-подобные рецепторы (TLR) были первыми идентифицированными PRRs (Рисунок) (Lemaitre, 1996; Medzhitov, 1997).

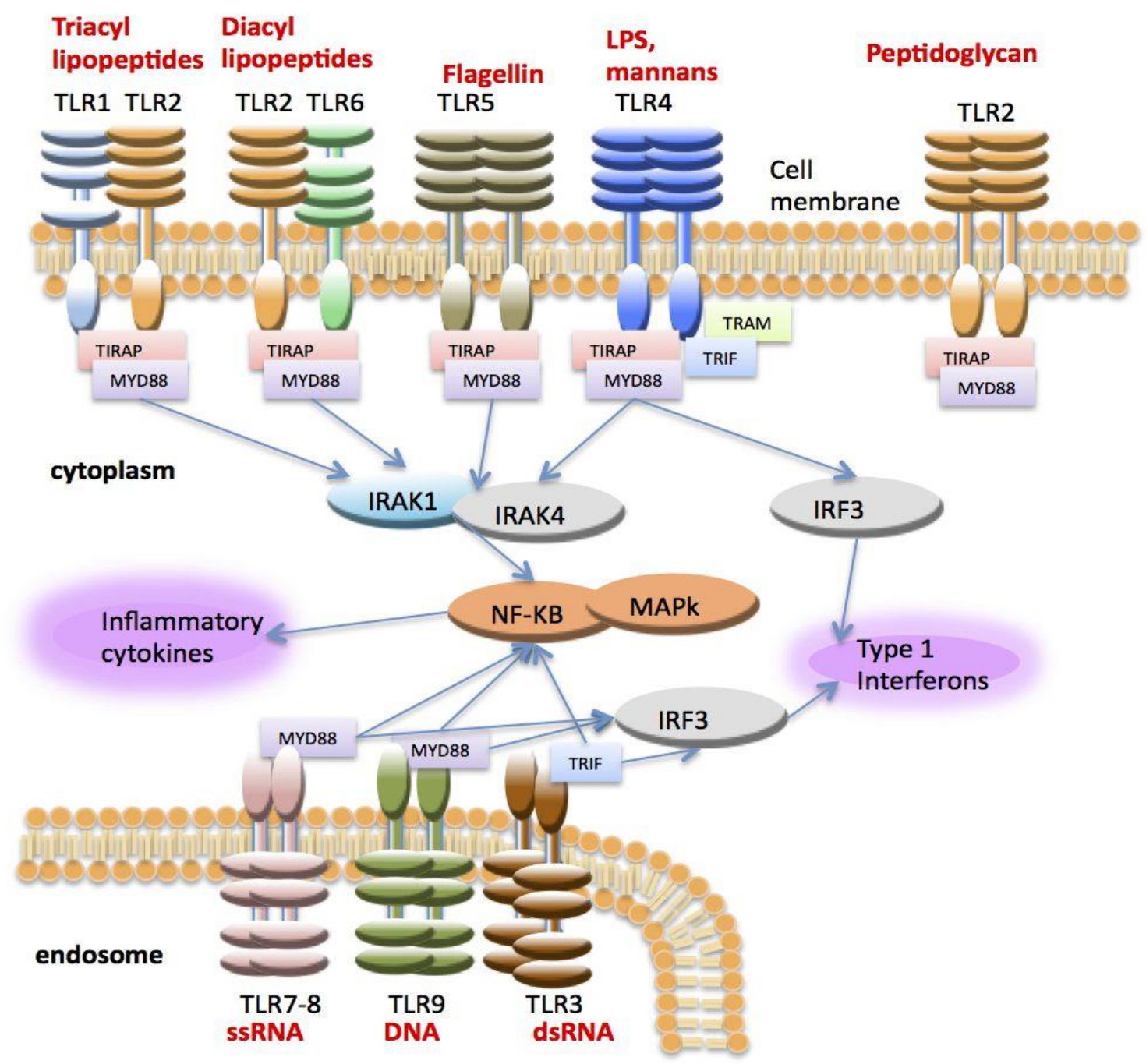

Рисунок. Активация воспалительных цитокинов и интерферона через TLRs начинается с распознавания TLR соответствующих агонистов (красный цвет). Взаимодействие адаптеров

TLRs и киназ (IRAK 1-4) приводит к активации NF-kB и MAР-киназ, основных регуляторов транскрипции цитокинов и интерферона (Lemaitre, 1996; Medzhitov, 1997).

Figure. Activation of production of inflammatory cytokines and interferon through TLRs is triggered by recognition of agonists by TLR (red). Interaction of TLRs adaptors with kinases

(IRAK 1-4) leads to activation NF-kB and MAP-kinases, which are the main regulators of transcription of cytokines and interferon (Lemaitre, 1996; Medzhitov, 1997). 
Для TLRs также наиболее подробно изучен и идентифицирован спектр PAMPs. TLRs - это трансмембранные белки первого типа, содержащие лейцин-богатые повторы в эктодомене, трансмембранный и цитозольные домены. Эктодомен узнает микробные паттерны, в то время как цитозольный домен активирует сигнальные пути в цитоплазме клетки. В зависимости от локализации TLRs в клетке выделяют рецепторы, расположенные в цитоплазматической мембране (TLR1, TLR2, TLR4, TLR5, TLR6, TLR10 и TLR11) или в мембранах внутриклеточных органелл (TLR3, TLR7, TLR8 и TLR9) - лизосом, эндосом, аппарата Гольджи. Лигандами рецепторов, локализованных на цитоплазматической мембране, являются поверхностные структуры микроорганизмов - липопротеин, липополисахариды, флагеллин, зимозан. Рецепторы, локализованные в мембранах внутриклеточных органелл, распознают молекулы ядерных структур микроорганизмов, но могут быть активированы и поврежденными молекулярными структурами собственного организма. Каждый TLR обнаруживает различные PAMPs вирусного, бактериального и другого происхождения. Так, например, липопротеины узнаются различными гетеродимерами из TLR1, TLR2 и TLR6 (Takeuchi, 1999), двуцепочечная PHK (DS) - TLR3 (Alexopoulou, 2001), одноцепочечная PHK (SS) - TLR7 и TLR8 (Hemmi, 2002; Heil, 2003), флагеллин - TLR5 (Smith, 2003), ДНК - TLR9 (Kumagai, 2008) (Таблица). TLR4 был первым рецептором с идентифицированным лигандом - бактериальным липополисахаридом (ЛПС) (Poltorak, 1998). В настоящее время у человека и мыши идентифицированы 10 и 12 функциональных TLR, соответственно.

Таблица. Toll-подобные рецепторы и их лиганды

\begin{tabular}{cccc}
\hline PRRs & Локализация & Лиганд & Происхождение лиганда \\
\hline TLR1 & мембрана клетки & $\begin{array}{c}\text { триацилипопротеин } \\
\text { липопротеины, } \\
\text { гликолипиды }\end{array}$ & $\begin{array}{c}\text { бактерии } \\
\text { бактерии, вирусы, } \\
\text { паразиты }\end{array}$ \\
\hline TLR3 & внутриклеточная & dsPHК & вирусы \\
\hline TLR4 & мембрана клетки & ЛПС & бактерии, вирусы \\
\hline TLR5 & мембрана клетки & флагеллин & бактерии \\
\hline TLR6 & мембрана клетки & диациллипопротеин & бактерии, вирусы \\
\hline TLR7 & внутриклеточная & sSPHК & вирусы \\
\hline TLR8 & внутриклеточная & sSPHК & бактерии, вирусы \\
\hline TLR9 & внутриклеточная & СрG-DNA & нет данных \\
\hline TLR10 & мембрана клетки & нет данных & простейшие \\
\hline TLR11 & мембрана клетки & профилин & \\
\hline
\end{tabular}

B состоянии покоя неактивированные TLRs находятся на мембране клеток в мономерной форме. После активации Тоll-подобных рецепторов происходит их олигомеризация. Олигомерный рецептор способен связывать несколько внутриклеточных адаптерных белков, которые обеспечивают последующую передачу сигнала. Эти белки имеют участок специфического связывания с активированными Тоll-подобными рецепторами, TIR (от англ. Toll-interleukin-1 receptor) домен, который состоит из 3 консервативных участков, участвующих в белок-белковом взаимодействии. Всего существует 5 адаптерных белков с TIR-доменом: MyD88, TIRAP, TRIF, TRAM и SARM. Различные рецепторы имеют свой набор этих адаптерных белков, необходимых для передачи сигнала. Только рецептор TLR4 способен связывать все 5 белков. 
Инициированная TLRs схема передачи сигнала внутрь клетки оставляет открытыми много вопросов. В частности, каким образом активация одного и того же Toll-рецептора в разных клетках приводит к продукции совершенно разного спектра цитокинов и других воспалительных белков. Например, известно, что TLR9 в макрофагах приводит к продукции классических цитокинов, таких как TNF и IL6, в то время как тот же TLR9 в плазмацитоидных дендритных клетках приводит к продукции IFN-I (Uematsu, 2005). Аналогично, будучи локализованным на клеточной мембране, TLR4 активирует классические цитокины, а транслокация в эндосому переключает TLR4 на продукцию типа 1 интерферона (Kagan, 2008). Только одним клеточным окружением трудно объяснить данную разницу.

Невозможно также объяснить с помощью такой простой схемы сложную и совершенную регуляцию многих сотен генов. Очевидно, что существуют дополнительные, неизвестные компоненты сигнальной активации с участием Toll-подобных рецепторов. Вероятно также, что все эти вопросы требуют дальнейшего изучения. Они соприкасаются с одной из наиболее интересных задач генетики, а именно: как относительно небольшим количеством генов, которое имеется у человека и многих других млекопитающих, кодируется огромное количество наблюдаемых фенотипов (фенотипических проявлений) (Benfey, 2008)?

Таким образом, установление функций генов остается одной из насущных задач современной биологии и генетики (Suzuki, 2006). В поисках решения этой проблемы Лаборатория молекулярной генетики врожденного иммунитета ПетрГУ в течение последних лет обратилась к эволюционно разнообразным линиям мышей, которые разошлись с общими предшественниками более миллиона лет назад (Guenet, 2003). С целью номенклатурного различия, эволюционно различные подвиды мышей получили название "диких мышей". В результате многие биологические процессы, включая иммунный ответ, в этих мышах будут активироваться по-другому, в сравнении с классическими лабораторными мышами (Stephan, 2007; Conner, 2008; Conner, 2009; Losick, 2009). Активация перитонеальных макрофагов с помощью ЛПС приводит к значительному повышению уровня TNF уже через 30 минут после активации. В то же время такой ингибитор активации как IL1R-антагонист начинает секретироваться через 24 часа после индукции (Brint, 2004). Как одни и те же клетки способны регулировать процессы активации и секреции, значительно разделенные по времени, пока не известно. Необъяснимыми являются и многие другие процессы. На страницах нашего журнала я призываю обсудить загадки и парадоксы Toll-подобных рецепторов клетки.

\section{Библиография}

1. Alexopoulou L, Holt AC, Medzhitov R, Flavell RA. Recognition of double-stranded RNA and activation of NF-kappaB by Toll- like receptor 3. Nature 2001, 413:732-738.

2. Benfey PN, Mitchell-Olds T. From genotype to phenotype: systems biology meets natural variation. Science 2008, 320:495-497.

3. Brint EK, Xu D, Liu H, Dunne A, McKenzie AN, O'Neill LA, Liew FY. ST2 is an inhibitor of interleukin 1 receptor and Toll-like receptor 4 signaling and maintains endotoxin tolerance. Nat Immunol 2004, 5(4):373-379.

4. Conner JR, Smirnova I, Poltorak A. Forward genetic analysis of Toll-like receptor responses in wild-derived mice reveals a novel antiinflammatory role for IRAK1BP1. J Exp Med 2008, 205:305-314.

5. Conner JR, Smirnova I, Poltorak A. A mutation in Irak2c identifies IRAK-2 as a central component of the TLR regulatory network of wild-derived mice. J Exp Med 2009, 206 (7):1615-1631.

6. Guenet JL, Bonhomme F. Wild mice: an ever-increasing contribution to a popular mammalian model. Trends Genet 2003, 19:24-31. 
7. Heil F, Ahmad-Nejad P, Hemmi H, Hochrein H, Ampenberger F, Gellert T, Dietrich H, Lipford G, Takeda K, Akira S, Wagner H, Bauer S. The Toll-like receptor 7 (TLR7)-specific stimulus loxoribine uncovers a strong relationship within the TLR7, 8 and 9 subfamily. Eur J Immunol 2003, 33:2987-2997.

8. Hemmi H, Kaisho T, Takeuchi O, Sato S, Sanjo H, Hoshino K, Horiuchi T, Tomizawa H, Takeda K, Akira S. Small anti-viral compounds activate immune cells via the TLR7 MyD88dependent signaling pathway. Nat Immunol 2002, 3(2):196-200.

9. Janeway CA, Medzhitov R. Introduction: the role of innate immunity in the adaptive immune response. Semin Immunol 1998, 10(5):349-350.

10. Kagan JC, Su T, Horng T, Chow A, Akira S, Medzhitov R. TRAM couples endocytosis of Tolllike receptor 4 to the induction of interferon-beta. Nat Immunol 2008, 9:361-368.

11. Kumagai Y, Takeuchi O, Akira S. TLR9 as a key receptor for the recognition of DNA. Adv Drug Deliv Rev 2008, 60:795-804.

12. Lemaitre B, Nicolas E, Michaut L, Reichhart JM, Hoffmann JA. The dorsoventral regulatory gene cassette spatzle/Toll/cactus controls the potent antifungal response in Drosophila adults. Cell 1996, 86(6):973-983.

13. Losick VP, Stephan K, Smirnova I, Isberg RR, Poltorak A. A hemidominant Naip5 allele in mouse strain MOLF/Ei-derived macrophages restricts Legionella pneumophila intracellular growth. Infect Immun 2009, 77:196-204.

14. Medzhitov R, Janeway CA. How does the immune system distinguish self from nonself? Innate immunity 2000, 343:338-344.

15. Medzhitov R, Preston-Hurlburt P, Janeway CA. A human homologue of the Drosophila Toll protein signals activation of adaptive immunity [see comments]. Nature 1997, 388(6640):394397.

16. Poltorak A, He X, Smirnova I, Liu MY, Huffel CV, Du X, Birdwell D, Alejos E, Silva M, Galanos C, Freudenberg M, Ricciardi-Castagnoli P, Layton B, Beutler B. Defective LPS signaling in $\mathrm{C} 3 \mathrm{H} / \mathrm{HeJ}$ and $\mathrm{C} 57 \mathrm{BL} / 10 \mathrm{ScCr}$ mice: mutations in Tlr4 gene. Science 1998, 282:2085-2088.

17. Smith KD, Andersen-Nissen E, Hayashi F, Strobe K, Bergman MA, Barrett SL, Cookson BT, Aderem A. Toll-like receptor 5 recognizes a conserved site on flagellin required for protofilament formation and bacterial motility. Nat Immunol 2003, 4:1247-1253.

18. Stephan K, Smirnova I, Jacque B, Poltorak A. Genetic analysis of the innate immune responses in wild-derived inbred strains of mice. Eur J Immunol 2007, 37:212-223.

19. Suzuki Y, Roth FP. Systematic genetics swims forward elegantly. Mol Syst Biol 2006, 2:48.

20. Takeuchi O, Hoshino K, Kawai T, Sanjo H, Takada H, Ogawa T, Takeda K, Akira S. Differential roles of TLR2 and TLR4 in recognition of gram-negative and gram-positive bacterial cell wall components. Immunity 1999, 11:443-451.

21. Uematsu S, Sato S, Yamamoto M, Hirotani T, Kato H, Takeshita F, Matsuda M, Coban C, Ishii KJ, Kawai T, Takeuchi O, Akira S. Interleukin-1 receptor-associated kinase-1 plays an essential role for Toll-like receptor (TLR)7- and TLR9-mediated interferon-\{alpha\} induction. $J$ Exp Med 2005, 201:915-923.

\section{Благодарности}

Работа выполнена при финансовой поддержке гранта Правительства РФ (Постановление 220), № 11.G34.31.0052 и гранта РФФИ-комфи, № НК 13-04-40267-Н/13. 